\title{
PUENTES, CAMINOS, RIOS: FRONTERAS COMO ARMAS DEFENSIVAS EN EXTREMADURA
}

\author{
POR \\ VALENTIN SORIA SANCHEZ
}

PRESENTAMOS en este trabajo los datos previos para delimitar las fronteras cambiantes de Extremadura. Ofrecemos nombres de puentes y ríos, de caminos, de montañas que sirven siempre de defensas naturales.

La estrategia tiene que contar en todo momento con estas armas en el planteamiento de los conflictos. Presenta la geografía gran importancia al defender y atacar los territorios en cada época histórica. Hemos seguido paso a paso estas corrientes de aguas y estos restos arqueológicos que nos hablan de poblaciones que ya no existen y de carriles y cañadas ahora olvidadas y que la vegetación de los montes ha ido borrando entre peñas $\mathrm{y}$ alturas.

Hemos preferido dar los documentos y las fechas y evitar los superfluos comentarios cuando la referencia histórica sobra.

Hemos puesto especial interés en la Edad Media porque ahí existen numerosos documentos, muchas veces olvidados. Gredos siempre ha sido barrera en nevados inviernos, entorpecimiento y dificultades en los días cálidos. La transhumancia ahora marcha en camiones y han dejado definitivamente los puertos y los puentes de esta Vera de Plasencia, punto de mira de muchas llanuras y comienzo de muchos itinerarios (Fig. 1).

En Plasencia hay un manuscrito del maestrescuela de la catedral Juan Correa Roldán. Fue redactado en 1579. Tal vez fuera familiar del sacerdote jaraiceño Gonzalo Correas Iñíguez (1571-1630), catedrático salmantino, doctor por la Universidad navarra de Irache y por la Universidad de Salamanca, autor de Arte de la gramática española castellana y de la Ortografía castellana y autor de un libro en hebreo sobre gramática hebrea, inédito todavía. Trae el privilegio de Alfonso VIII de 8 de marzo de 1189. Mi recordado amigo Domingo Sánchez Loro, correspondiente de la Real Academia de la Historia, traduce el documento en su reciente libro Historias placentinas inéditas (pág. 43):

Por lo cual yo Alfonso por la gracia de Dios rey de Castilla y de Toledo juntamente con mi esposa la reina Leonor y con mis hijas las infantas Berenguela y Urraca para gloria de Dios en el lugar que antiguamente se llamaba 


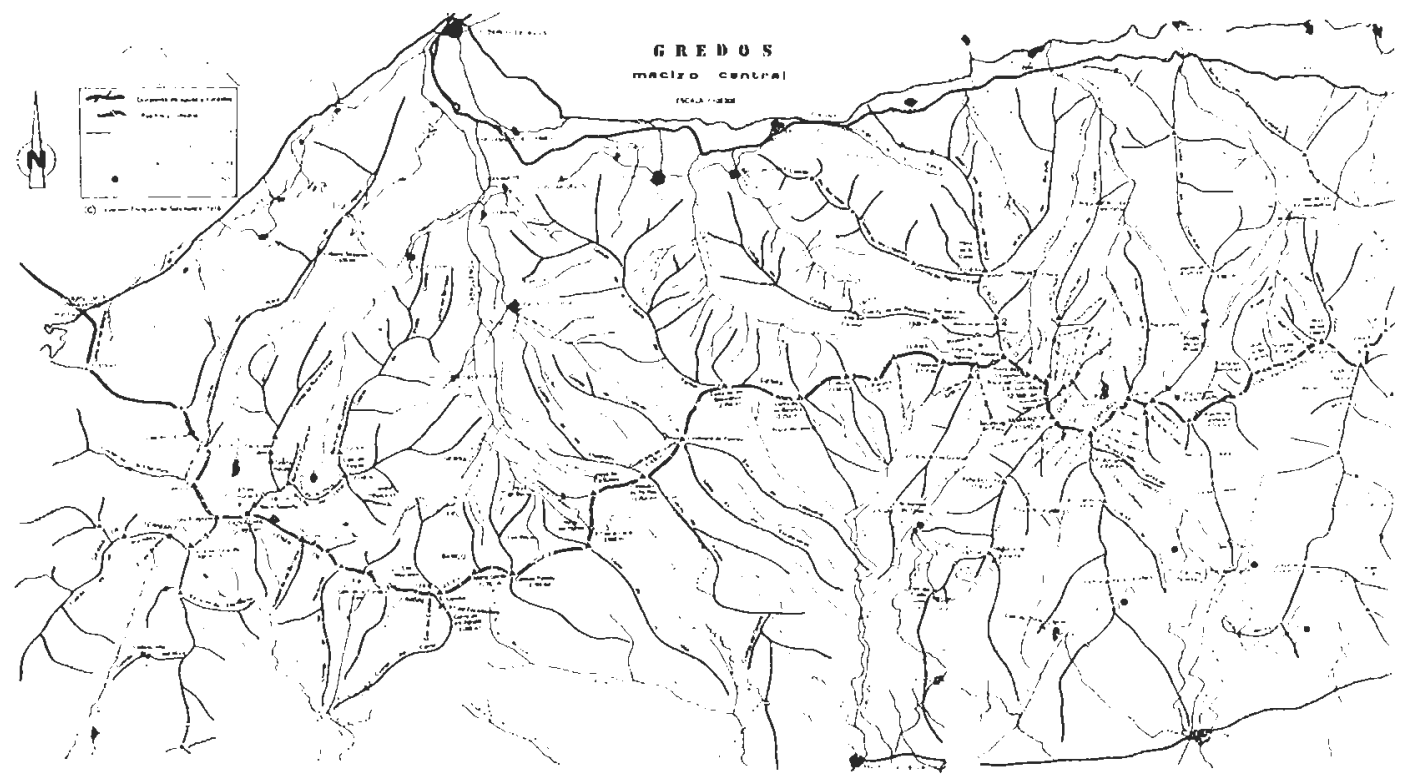

Fis.. 1-La sierra de los Gredos siempre ha sido barrera en nevados invernales y entorpecimiento en los días cálidos.

Ambroz edifico una ciudad a la que puse (4 diciembre 1186) el nombre de Plasencia para que agradc a Dios y a los hombres.

$\mathrm{Y}$ a ella $\mathrm{y}$ a su concejo presente y futuro y a sus hijos y descendientes asigno doy y concedo términos según las lindes especificadas en los mojones situados entorno a la ciudad descritos y puestos en la siguiente forma con sus bosques $\mathrm{y}$ aguas y fuentes $\mathrm{y}$ con todos sus derechos $\mathrm{y}$ pertenencias para que tengan y posean los dichos términos desiertos o poblados según quisiercn para pasto o para agricultura y de ellos y en ellos hagan lo que les plazca.

En las partes que se hallan allende del Tiétar posean los términos junto al Tajo según se le cruza por el vado de Alarza que hay en el Tajo yendo derecho a la Cabeza Mayor de la Pedernalosa. Y de la Pedernalosa en directo a Cabezas cle Terrazas. Y de Cabezas de T'errazas en directo hasta el río Tiétal (Fig. 2).

Y pasado el Tiétar hasta la garganta de Chiella. Y de la garganta de Chiella por el camino recto que llega hasta lo último de Valle Vellido lel mupa de mi buen amigo Delgado Ubada Julián pone Babellido en su moderno mapa de alta montaña]. Y por el Valle. Vellido adelante según se va en directo a la Cabeza de don Pedrolo. Y de la Cabeza de don Pedrolo adelante según entra el camino en el río Tormes. Y en el río Tormes adelante hasta el arroyo de Mula cuando entra en el Tormes. Y el arroyo de Mula arriba segín se dirige a lo alto de Falgoso. Y de Falgoso adelante según se va a la Calzada de Guinea. 


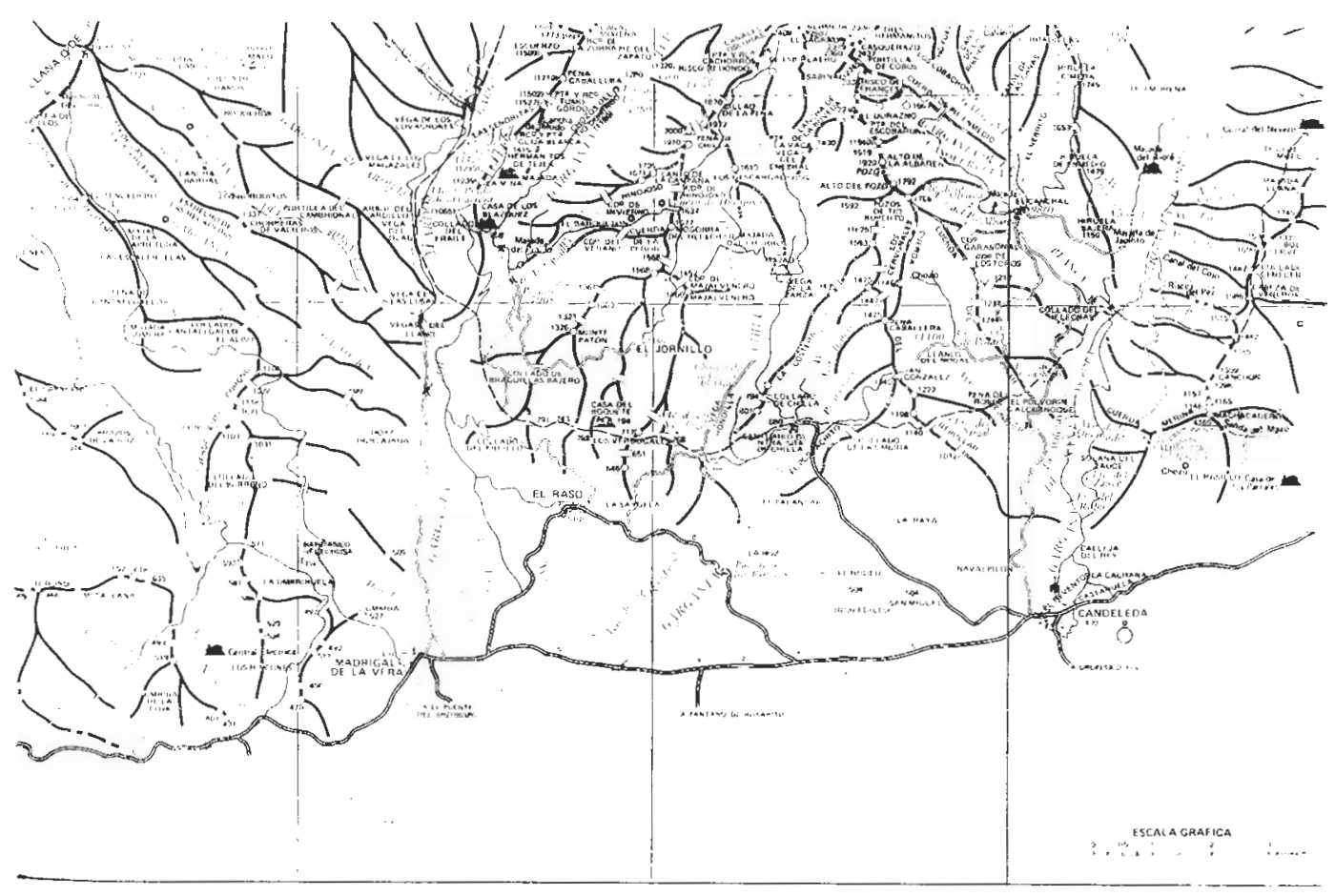

Fig. 2.-Parte de la Vera, entre los Gredos y el río Tiétar.

Y más allá dol río Tajo desde el supradicho vado de Alarza según el camino sale del vado y por el que se llega hasta el puerto de Ibor exceptuando el castillo de Albalat con su término que se halla según caen las aguas junto al castillo desde las tierras más allá del Tajo. Y desde el puerto de Ibor según se va derecho al río que se llama Almonte. Y el Almonte adelante hasta donde el Geblanco vierte en el Almonte.

Y el Geblanco arriba según se va al Tamuja y en directo a Zafra de Montánchez y al campo de Lucena y a la Sierra de San Pedro y siguiendo la línea de esta demarcación todo lo que los placentinos puedan adquirir. Y dentro de los referidos linderos concedo Monfrag por aldea pero reservándome yo el castillo... Hecha esta carta en Plasencia era de 1227 (año 1189) 8 de las idus de marzo, segundo año después que el serenísimo Alfonso rey de Castilla y de Toledo armó con el cíngulo de la milicia a Alfonso rey de León y el mismo Alfonso rey de León besó la mano al dicho Alfonso rey de Castilla y de Toledo y el mismo ya repetido Alfonso ilustre rey de Castilla y de Toledo armó bravo caballero al hijo del Emperador de romanos de nombre Conrado y le dio a su hija Berenguela por esposa. Y yo Alfonso reinante en Castilla y en Toledo rubrico y confirmo esta carta con mi propia mano. 
El 2 de enero de 1178, Alfonso VIII concede al obispo de Avila, don Domingo, las tercias de todas las rentas reales de Plasencia habidas y por haber. El 13 de marzo de 1188, Alfonso VIII concede al arcipreste de Avila y arcediano de Plasencia, don Pedro Tajabor, una presa en el río Jerte más la iglesia de Santa María, hallada intacta al tiempo de la reconquista en 1178 .

El 14 de noviembre de 1221, Honorio III extiende la siguiente bula, que traducida dice así:

Honorio obispo siervo de los siervos de Dios al vencrable hermano obispo y a los queridos hijos en el cabildo placentino salud y bendición apostólica. En los he: hos de feliz recordación del papa Clemente nucstro antecesor hallamos unas letris en la siguiente forma. Clemente obispo siervo de los siervos de Dios al rey querido hijo nuestro ilustre rey de Castilla salud y bendición apostólica....

De acuí en que valorando en todos sus matices el regio deseo de ampliar los confines de la religión católica ya manifestado en la ciudad placentina en tierra sacada con vuestra diligencia del poder de los hismaelitas hicisteis poblar con la ayuda de la clemencia divina constituimos con autoridad apostólica una cátedra episcopal. Mandamos que dicha iglesia catedral posea tuna diócesis de actrerdo con el mandamiento real y como villas según en el presente escrito se consigna que son suyas concedidas por su liberalidad deben pertenecerla con derecho diocesano para siempre esto es Trujillo, Medellín, Monfrague y Santa Cruz con todas sus pertenencias... Dado en Letrán el décimo octavo día de las kalendas de diciembre año quinto de nuestro pontificado (14 diciembre 1221). Otra bula pontificia marca las fronteras y lindes de la diócesis. Dicc así Honorio obispo siervo de los siervos de Dios al venerable hermano en Cristo considerando el obispo placentino salud y bendición apostólica...

Por lo cual venerable hermano en Cristo considerando tus justas peticiones con agradable beneplácito te confirmamos con autoridad apostólica las iglesias de Béjar y sus términos según los poseéis en justicia y en quietud y los aseguramos con el valor del presente escrito.

Dada en Letrán el décimo sexto día de las kalendas de diciembre año primero de nuesrro pontificado. Año 1186.

Entre el obispo de Plasencia y el obispo de Avila hubo pleito sobre las iglesias de Béjar y su jurisdicción y Tornavacas, y se comprometió con el obispo de Zamora y otros jueces árbitros, los cuales adjudicaron Béjar y Tornavacas al obispado de Plasencia, dice Juan Correa Roldán (Sánchez Loro, D., pág. 57). El 10 de noviembre de 1221, un privilegio real confirma los términos del obispado de Plasencia de esta manera:

Por el presente escrito sea conocido y manifiesto tanto a los presentes como a los venideros que yo Fernando por la gracia de Dios rey de Castilla y de Toledo juntamente con mi esposa la reina Beatriz y mi hermano el infante Alfonso con asentimiento y bencplácito de la reina doña Berenguela mi madre hago carta de concesión confirmación a perpetuidad a Dios y a la iglesia de 
Plasencia y a vos mi venerable amigo Domingo su actual obispo y a todos sus sucesores en el presente y en el futuro con validez para siempre.

Así pues os concedo y confirmo a Plasencia con todos sus términos según os los dio en otro tiempo mi abuelo el ilustre Alfonso de feliz memoria y Béjar que comprobé hallarse dentro de sus términos. También Trujillo, Meclellín, Santa Cruz, Montánchez, excepto los derechos que tenga en ellos la iglesia de Toledo si tiene alguno y el Monte Fragoso para que todos ellos los poséíis indefinidamente en la jurisdicción diocesana...

Hecha la carta en San Justo de Alcalá el día cuatro de las idus de noviembre, era de mil doscientos cincuenta y nueve, año quinto de mi reinado (Año 1221). Y yo el ya dicho rey Fernanclo reinante en Castilla y en Toledo esta carta que mandé hacer la rubrico con mi propia mano y la confirmo. Rodrigo arzobispo de la sede de Toledo primada de las Españas confirmo... Lope Obispo de Siguienzal... Domingo obispo de Avila confirmo. Domingo obispo de Plasencia confirmo, etc.

El manuscrito del siglo xIX del capellán José María Barrio y Rufo (Sánchez Loro, D., pág. 67), en el folio 74, dice así:

El reino de León se dividía del de Castilla como don Alfonso el emperador abuclo del rey don Alfonso fundador de Plasencia le dividió a sus dos hijos don Sancho y don Fernando... Dio al mayor de sus hijos don Sancho a Castilla hasta Sahagún, también a Medina, a Arévalo y a toda la tierra de Avila y Tolcdo hasta la calzada que era camino real de los romanos que viene desde Salamanca y atraviesa Extremadura.

Según la divisoria de la calzada que se llama de Guinea, y en Asturias según la divisoria del río Ove hasta la parte del mar, y dio Portugal a Fernando su hijo menor... De suerte que Coria, Badajoz, Ciudad Rodrigo, Salamanca, Zamora, Toro, etc., y toda Galicia pertenecían al reino de León. Plasencia, Béjar, Trujillo y Medellín a Castilla.

Vienen reunidos ambos reinos desde el rey don Fernando el Santo. Existe un privilegio real de Fernando III que dice así (Sánchez Loro, D., pág. 69):

Fernando rey de Castilla de León y de Galicia de Córdoba y de Jaén etc. con beneplácito de la reina doña Berenguela mi madre hago carta de donación al concejo de Plasencia presente y futuro y os dono por los muchos servicios que me hicisteis el castillo de Monfrague que recibí para mí de los hermanos calatravenses con todos sus servicios y términos. Dado en Jaén 28 de agosto de 1284, en el mismo año que el dicho rey conquistó de los sarracenos la ciuJad de Jaén (1246). Rodrigo arzobispo toledano de la sede compostelana y Adán obispo placentino y otros confirman.

Hay otro privilegio real que dice lo siguiente sobre el castillo de Belvis (Sánchez Loro, D., pág. 72):

Fernando rey de Castilla y de Toledo. Hago carta de donación de concesión y confirmación a vosotros el concejo de Plasencia presentes y futuros porque os hallo fieles y dispuestos a mis servicios os concedo aquella carta plo- 
mada que os dió mi famosísimo abuelo el rey Alfonso que os pobló y lo que en ella se dice. También os concedo el castillo de Belvis con su término para poblarlo y cultivarlo.

Hecha la carta en Burgos 18 de septiembre era 1259. Año 1221. Rodrigo primado de las Españas toledano. Domingo obispo placentino y otros confirman.

El manuscrito del maestrescuela Juan Correa Roldán (Sánchez Loro, D., pág. 73) dice:

La dicha villa de Cabañas fue aldea de Trujillo y sobre ella traen pleito que está pendiente.

Las villas de Serrejón y Talaván que fueron de García Fernández de Helrera y después de doña Ana de Herrera su hija vinieron por casamiento a poder del conde de Benavente que las posee. Son de este obispado.

La villa de Jarandilla deste obispado que posee el conde de Oropesa. La villa de Tornavacas deste obispado posee el conde cle Oropesa (Fig. 3). La viIla de Garganta la Olla deste obispado posee el marqués de Villena. La villa de Valverde de la Vera deste obispado posee el conde de Nieva. La villa de Pasarón deste obispado posee el conde de Osorno. La villa de Mirabel deste

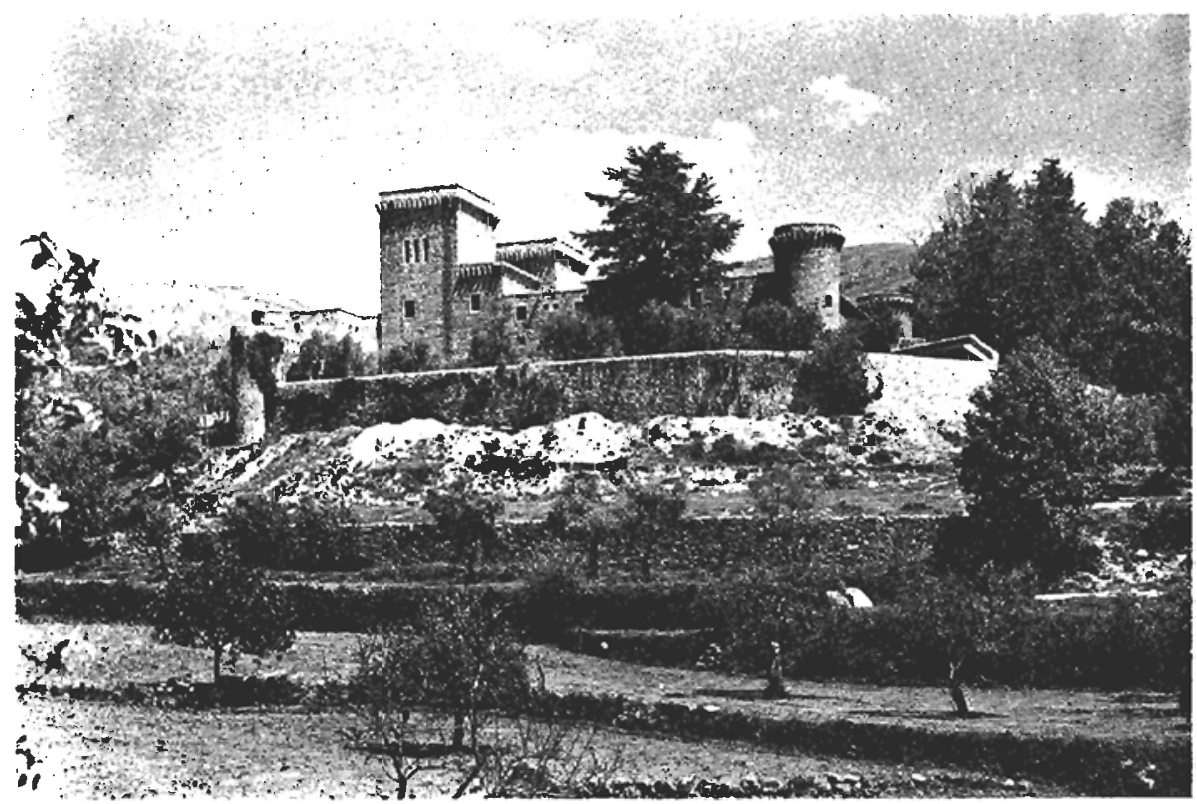

Fig. 3.-Castillo-Palacio de los Condes de Oropesa, en Jarandilla, antes de su restauración. Paradero del emperador Carlos V en su ruta hacia el monasterio de Yuste. (Hoy, Parador Nacional de Turismo «Carlos V».) 
obispado posec el marqués de Mirabel. La villa de Torrejón el Rubio deste obispado posee don Francisco de Carvajal. La villa de Monroy y las Quebradas deste obispado posee don Fernando de Monroy. La villa de la Oliva que era del término de Plasencia y la villa de Plasenzuela del término de Trujillo deste obispado posee don Luis de Camargo. La villa de la Serradilla se gobierna por alcaldes ordinarios.

Iodas las dichas villas eran de la jurisdicción temporal de la ciudad de Plasencia de la cual ya son exentas. La villa de Orellana la Vieja deste obispado posee don Juan Alonso de Orellana. La villa de Orellana de la Sierra deste obispado posee don Pedro de Orellana. La villa del Puerto (de Santa Cruz) deste obispado posee don Diego de Vargas. La villa de la Cumbre deste obispado posee don Juan de Barrantes. La villa de Marta (Santa Marta de Magasca) deste obispado posee Alvaro de Loaisa. La villa de Torrecillas (cerca de Garciaz y Aldeacentenera) deste obispado posee Diego Pizarro de Hinojosa. La villa de Madronera deste obispado posee Alonso Ruiz y sus herederos. La villa de Berzocana deste obispado nombrada por los cuerpos de los Santos Leandro e Isidoro arzobispos de Sevilla hermanos de los Santos Fulgencio y Santa Florentina se gobierna por alcaldes ordinarios. Las villas de Cañamero y de Garciaz deste obispado se gobiernan asimismo por alcaldes que entre sí se eligen. Fueron todas de la jurisdicción de Trujillo de la cual ya por privilegio de los reyes son exentas.

\section{El manuscrito del capellán José María Barrio Rufo (Sánchez Loro, D.,} pág. 74) dice así:

Las 42 aldeas de la fundación de Plasencia están divididas en tres sexmos. Advierto que varias de ellas han sido declaradas villas por diferentes gracias concedidas por los reyes. El sexmo de la Vera tiene diez lugares. Pónense por la antigüedad como iban votando para la elección de procurador general y sus sexmeros que lo verificaban cada tres años. Esto ya no existe por las leyes constitucionales vigentes: Losar, Aldeanueva, Robledillo, Collado, Cuacos, Jaraíz, el Atalayuela, Arroyomolinos, 'Texeda, Gargüera.

Campo de Arañuelo tiene aldeas menudas, 10 concejos y 18 lugares. Aunque Mirabel y la Serradilla son villas pertenecen al sexmo este así que no quedan sino 16 aldeas: Malpartida, Casas de Millán, Toril, Casatejada, Majadas, Saucedilla, el Concejo de la Campana de Albalat tiene a Romangordo, Piñuela de Arriba, la Piñuela de en Medio, la Higuera y las Casas del Puerto, el Concejo de la Campana de la Mata, Navalmoral, La Peraleda, Valparaíso, Malhincada y Torviscoso.

Valle y Transierra, 15 concejos y 17 lugares, Xerete (hoy Jerte), Vadillo, éste en el día (siglo XIX) despoblado, Cabezuela, Navaconcejo, Rebollar, el Barrado, Piornal, la Oliva, la Campana de Ojalvo que son tres pueblos, Valdastillas, Casas del Castañar, Asperilla (no subsiste de él más que dos o tres casas), el Torno, el Cabrero, Cabezabellosa, Villar, Jarilla, Segura y Gargantilla.

Continúa diciendo el manuscrito del capellán José María Barrio Rufo (Sánchez Loro, D., pág. 82):

Y cl río de Cáparla se llamaba Flumen Ambracia, río de Ambracia. He querido advertir porque se hace notable agravio a la antigüedad de esta ciudad teniéndola por lugar nuevo pues antes de la reedificación o fundación del rey 
don Alfonso y antes de los moros, y aun de los godos y romanos había población por estas palabras de una bula del pontífice Clemente III se ve claramente. Este Papa fue el que erigió la silla pontifical de esta ciudad año de 1189 a instancia del rey don Alfonso VIII su fundador en que se ve claramente haber habido población.

Dice la bula: De aquí que valorando en todos sus matices el regio deseo de ampliar los confines de la religión cristiana ya manifestado en la ciudad placentina en tierra sacada con vuestra diligencia del poder de los hismaelitas hicisteis poblar con ayuda de la clemencia divina constituimos con autoridad apostólica una cátedra episcopal.

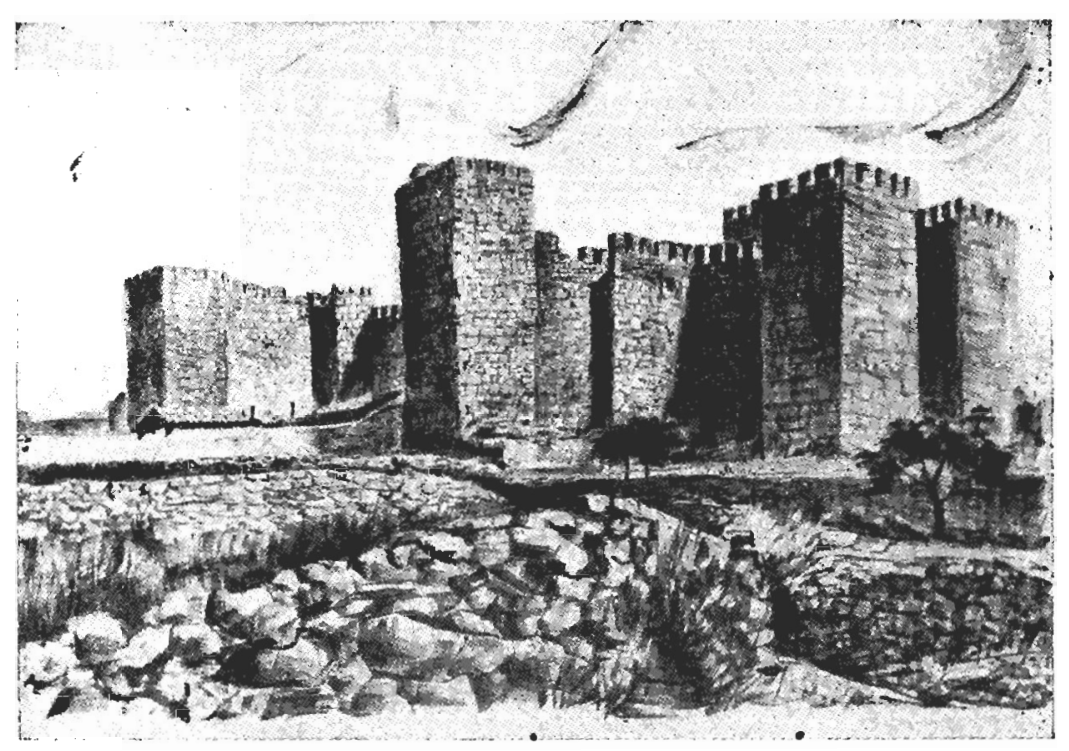

Fig. 4.-Castillo de Trujillo. Típico ejemplar árabe dei siglo xi. Ha conservado su planta original, pero entre los siglos xilI y xv se ha añadido capilla y otros elementos. (Dibujo de F. Castillo.)

Mandamos que dicha iglesia catedral posea una diócesis de acuerdo con el mandamientu real y como villa según el presente escrito se consigna que son suyas concedidas por su liberalidad deben pertenecerla con derecho diocesano para siempre, esto es, Truilllo (Fig. 4), Medellín, Monfrague y Santa Cruz con todas sus pertenencias.

Esto dice más claro la Historia de España de Juan de Mariana, libro XI, capítulo XIV: 
Fue asentada la ciudad de Plasencia en el fin del reino e ilustrada de obispo donde primero habia una como aldea llamada Ambroz, el cual nombre se mudó en Plasencia como pronosícando de ella que iba a agradar a Dios y a los hombres y también por la amenidad agradable de la región.

De estas palabras se colige claramente que donde se fundó la ciudad había población. El manuscrito de José María Barrio Rufo sigue hablando de la antigüiedad de Plasencia (Sánchez Loro, D., pág. 86):

Sin cllos lo afirman el padre Jerónimo Román de la Higuera (siglo xv1) que en su Flistoria número cuarenta y cinco dice lo siguiente: «De Ambracia in Lusitania quac numc Ambracia Placentia jam saepius alias...» Extremadura sc conoció con el nombre de Jusitania y Vetonia.

Florián de Ocampo la demarca perfectamente y Plinio en el libro IV capítulo 22 dice que están en Lusitania los pueblos: augustobrigenses, ammienses, aranditanos. Y lucgo entrando en nuestro distrito prosigue: axabrarenses, belvenses (Belvis), caesarobrigenses (Oliva), caparenses (Caparra), caurienses (Coria), Axabricenses. En el referido Plinio son los ambracenses de Dextro Luitprando y Juliano y los clel fragmento de San Atanasio y Calidonio de sucrte que Plasencia era Ambracia y no Axabracia.

El manuscrito de José María Barrio Rufo (Sánchez Loro, D., pág. 94) continúa diciendo:

Edificó también esta ciudad de Plasencia en la parte de la provincia de Lusitania que los antiguos llamaron Vetonia y nosotros Extremadura habiendo ganado a los moros el lugar de Ambroz como parece por el privilcgio de su fundación que tiene esta ciudad de Plasencia. Fecha en ocho de marzo era 1227 (Añu 1189) que comienza: «Quanto largius fides pullulat» etc. y acaba «manu propria roboro et confirmo».

El cual privilegio tue confimado por el rey don Alfonso $X$ que llamaban el Sabio bisnieto del rey don Alfonso funclador de la ciudad el año 1273, 18 de junio en Segovia. También lo fue por don Sancho el Bravo su hijo el 6 de agosto del año 1280. Por el rey don Fernando el IV en Valladolid a 13 de junio de 1307. Después fue confirmado por el rey don Felipe II en Madrid el 24 de abril de 1573. Como por también por su hijo Felipe III en San Martín de la Vega el 22 de enero de 1599.

El privilegio del rey don Alfonso, el fundador, está inserto en otro privilegto de su bisnieto, el rey don Alfonso el Sabio, del tenor siguiente:

Sepan cuantos esta carta vieren como nos don Alfonso rey de Castilla, de Toledo, de León, de Galicia, de Sevilla, de Córdoba, de Murcia, de Jaén y del Algarve vimos un privilegio del rey don Alonso nuestro bisabuelo sellado de su scllo fecho en csta guisa: «Quanco largius... roboro et confirmo.»

$Y$ nos el sobredicho rey don Alonso reinante en unión con la reina doña Violante mi mujer con nuestros hijos el infante don Fernando mi primer heredero y con don Sancho y con don Juan en Castilla, en Toledo, en León, en Galicia, en Sevilla, en Córdoba, en Murcia, en Jaén, en Baeza, en Barlajoz y en el Algarve otorgamos este privilegio y lo confirmamos y mandamos que 
valga así como valió en la sazón que el rey don Alfonso nuestro bisabuelo lo dio. Y para que sea firme y estable mandámoslo sellar con nuestro sello de plomo. Hecho el privilegio en Segovia domingo 18 días andados del mes de junio cra 1311 (Año 1273).

Por este privilegio fundamental constan los términos que le dio de esta y de la otra parte del Tajo y hasta el río Almonte, y por la parte de la Vera y Valle y Piedrahíta hasta el Tormes (hasta el nacimiento del Tormes, es decir, hasta la laguna del pico Almanzor). Queda detallado en el mapa posterior de Tomás López, en 1760.

Un manuscrito de Ascensio Morales y Tercero (Sánchez Loro, D., pág. 118) traducido dice lo siguiente:

$Y$ a su ejemplo no moraba solo en una ciudad (habla de San Pedro de Rates, alæubispo de la ciudad bracarense) sino por su celo de su fe más acá del Micditerránco y más allá del Tajo y atrayendo a los pueblos que tenía encomendados en Égitania, Collense, Emerita, Ambracia y en otras ciudades de los vetones y lusitanos difundió la palabra de Dios.

En el mismo manuscrito (Sánchez Loro, D., pág. 123):

... lo cita Tamayo siguiendo el Cronicón de Dextro y se empeña en defender quc este Splendonio es el mismo que siendo obispo de Ambracia asistió al concilio primero cesaraugustano dando por razón que por aquel siglo no había otro obispo de este nombre.

Pero siendo constante que para la existencia del expresado no hay más fundamento que el Cronicón de Dextro en que dice «... heretici priscillianistae ab urbe Vettonum Ambracia ignominiose depelluntur a Splendonio hujus urbis episcopo.» Los herejes priscilianistas fueron arrojados ignominiosamente de la ciudacl vetona de Ambracia por Splendonio obispo de esta ciudacl.

El manuscrito de Áscensio Morales Tercero (Sánchez Loro, D., página 127) afirma lo siguiente:

... he hallado copia auténtica del privilegio que el señor rey don Alonso concedió a la iglesia señalándose los términos de su diócesis incluso en otro uriginal del señor rey don Fermando expedido en San Justo de Alcalá a cuatro de las idus de noviembre era 1259 , correspondiente al año 1221. E igualmente una copia de la erección de la referida iglesia inclusa en otra en una confirmación cspecífica de ella que expidió el Papa Honorio III a 18 de las kalendas de diciembre año quinto de su pontificado que concurrió con el año 1216. $\mathrm{Y}$ otra del mismo Pontífice contirmando los términos asignados al obispado que anteriormente expedido el año primero clada en Roma en el palacio lateranense a 16 de las kalendas de diciembre año 1221 . Y en el archivo de la ciudad cle Plasencia se ha hallado auténtico el privilegio de la fundación de ella.

Con lo cual queda probado suficientísimamente la relación hecha cuando no bastasen la tradición e historias en unos hechos tan modernos en que no se da lugar ni a la disputa ni a la duda. Fue esta iglesia de Plasencia sujeta desde su erección al metropolitano de Santiago (Fig. 5). Y como fundación 


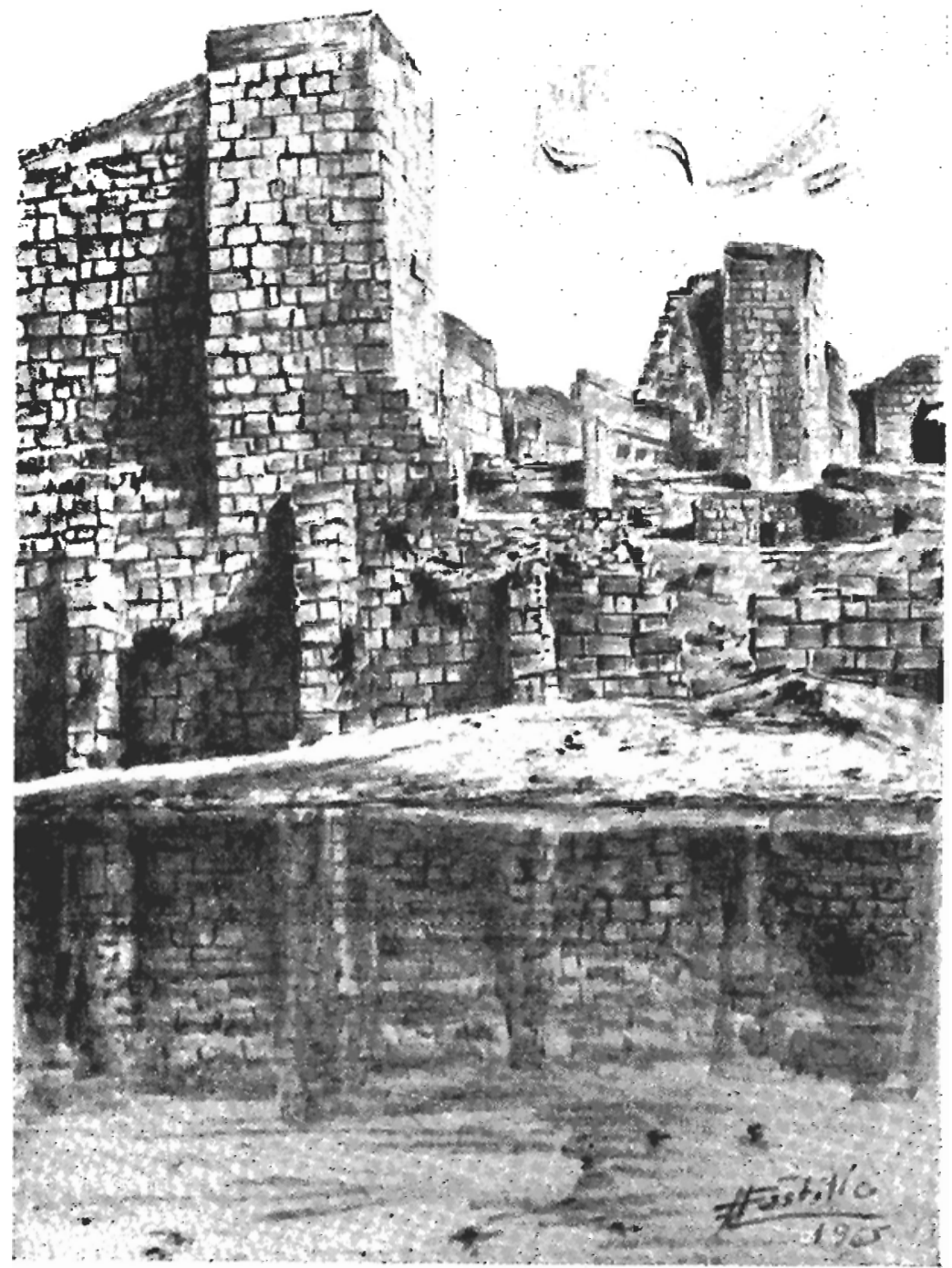

I'1c. 5.- Mlcazaba de Mérida, construido por los árabes en el siglo xil sobre fundamentos romanos. Sirvió más adelante como conventual de la Orden de Santiago. (Dibujo de F. Castillo.) 
moderna y de ticmpo en que ya se habían empezado a secularizar las iglesias y cabildos nunca fue la institución de canónigos bajo del pie de regulares. $Y$ como quiera que para su establecimiento era preciso que se ofreciesen muchas dudas y dificultades con los obispos convecinos no basta a lo que se entiende la concordia que entre el obispo tercero de Plasencia don Adán y el de Avila se tomó sobre el territorio de Béjar y Tornavacas que confirmó el papa Gregorio XI sucesor de Honorio por la bula original que subsiste dada en Perusa noveno año de su pontifícado a dos de las idus de julio de 1235 . $Y$ fue preciso que el expresado don Adán acompañado de don Martín Pedro su deán fuese a Roma por el año de 1254 a arreglar el referido asunto y las cosas de la iglesia a la mejor disciplina. $Y$ en efecto fue tan útil esta diligencia que el pontítice Inocencio IV cometió estos negocios al cardenal de los Santos Cosme y Damián Egidio, su legado en estos reinos quien desempeñó el encargo con entera satistacción pues dispuso la nueva planta de la iglesia de dignidades, canongías, raciones, beneficios y formó los convenientes estatutos. Que uno y otro aprobó Su Santidad por su bula expedida a este fin que va compulsada.

En un manuscrito del médico placentino Celso Monge (Sánchez Loro, D., pág. 147) escribe lo siguiente:

Esto mismo indica el padre Fray Luis de Ariz quien su Historia antigua de Avila, parte 1, folio 8, dice que la población que había en Plasencia junto a una torre que ahora está en la fortaleza y se llama de la Torre de Ambroz por los años de 1181 pertenecía al Obispo de Avila y el Pontífice Lucio III comisionó a los obispos de Salamanca y Zamora para que compeliesen a los vecinos que obedeciesen como a su prelado al obispo de Avila.

En el manuscrito del médico placentino Luis de Toro, de 1573, redactado en latín, se resume el privilegio de Alfonso VIII fundando Plasencia (Sánchez Loro, D., pág. 156):

Cuanto más ampliamente la fe se propaga y la cristiana religión se acrecienta tanto más se glorifíca a la Majestad Divina con la invocación de su divino nombre y se asegura a sus fieles lo prometido. Por ello es piadoso y conveniente a la salud de las almas construir ciudades en estos lugares limítrofes a la región de los paganos y plantar comunidades cristianas que contrarreste la iniquidad de los infieles para loanza y gloria del Creador de todas las cosas. Por lo cual yo Alfonso por la gracia de Dios rey de Castilla y de Toledo juntamente con mi esposa Leonor y con mis hijas Berenguela y Urraca para gloria de Dios en el lugar que antiguamente se llamaba Ambroz edifico una ciudad a la que puse el nombre de Plasencia esto es que agrade a Dios y a los hombres. Hecha la carta en Plasencia era de 1227 (Año 1189) 8 de las idus de marzo segundo año después que el mismo serenísimo Alfonso rey de Castilla y de Toledo armó con el cíngulo de la milicia al rey de León y el mismo rey de León Alfonso besó la mano dẹl dicho Alfonso rey de Castilla y de Toledo. Y el mismo ya repetido Alfonso de Castilla y de Toledo armó caballero al hijo del emperador de los romanos de nombre Conrado y le dio por esposa a su hija Berenguela. Yo Alfonso reinante en Castilla y en Toledo rubrico esta carta con mi propia mano. 
El médico placentino Luis de Toro escribe lo siguiente sobre los límites de Plasencia (Sánchez Loro, D., pág. 158):

Plasencia tuvo en los tiempos pasados como del mismo privilegio real se deduce una muy amplia y dilatada jurisdicción de tierras ya que se extendía por el oriente hasta el río Tormes y por occidente hasta más allá de Trujillo o sea hasta Montánchez. Mas una parte fue incluida por los reyes en las donaciones de tierras, otra parte fue vendida, otra parte fue usurpada por limítrofes y tan consumada la hallamos (en 1573) que veremos a los vecinos estrecharse en un breve círculo.

Por cierto, que Luis de Toro dibuja en su manuscrito un círculo dividido en cuatro partes con límites diocesanos. Cita a Madrigalejo (hoy, Madrigal de la Vera), por oriente; Fresnedoso, por el mediodía, y Tornavacas, por el norte. Luis de Toro habla detalladamente de los límites de la diócesis placentina (Sánchez Loro, D., pág. 208):

Tíne además el obispado de Plasencia una muy amplia y dilatada jurisdicción de señorío y dominio pues tomando su principio entre el septentrión y el oriente desde el lugar de la Cabeza del ducado de Béjar en cuya parte limita con el obispado de Salamanca discurre en dirección oriental por montes asperísimos y escarpados hasta Madrigalejo (hoy, Madrigal de la Vera) lugar del conde de Nieva que es el último de la Vera y limita con el obispado de Avila (Fig. 2).

De aquí en dirección recta hacia el mediodía cruzando el llamado Campo de Arañuelo llega a la heredad de San Benito del Marqués de Mirabel. Luego por junto a la Peraleda (de la Mata) del río Tajo llega al monte de Fresnedoso incluido dentro del obispado placentino. Desde aguí sigue por las altísimas y elevadas cumbres de los montes llamados Cecilia Gemellina que vulgarmente dicen de Santa María de Guadalupe por cuyos extremos limita con el arzobispado de Toledo.

Desde aquí va directamente hacia el río Guadiana y al lugar de Navalvillar de Pela y a las Orellanas que dicen Nueva y Vieja. Desde aquí siguiendo la dirección del mediodía el obispado se extiende más allá de la región de Medellín hasta occidente y aquí limita con el maestrazgo de Santiago de la Espada. Después volviendo en derechura al lugar de origen por el lado norte y del septentrión el obispado de Coria limita con el nuestro. Por lo tanto si desde el principio es decir desde el primer lugar de la Cabeza de Béjar echásemos una línea hasta la región de Medellín a donde limita con el obispado pacense tendríamos seguramente 1172 de longitud y descle San Pedro de Palacios hasta Fresnedoso 1052 de latitud. Comprende en total la diócesis de Plasencia cerca de doscientos lugares. Las cuatro demarcaciones se denominan: Plasencia, Trujillo, Medellín y Béjar (Fig. 3).

En el manuscrito del siglo xvi del jesuita Jerónimo Román de la Higuera (Sánchez Loro, D., pág. 237) se lee lo siguiente:

El año 1187 se reformó la orden de Calatrava. Este mismo año como consta por escrituras se intitula el rey don Alonso rey de Castilla, de Toledo, de Plasencia, cle Cuenca a más de toda Extremadura, Burgos, Nájera, Calahorra. 
Donde se ve la estima que hace el rey de la ciudad de Plasencia y de Toledo pues las antepone a Burgos. Y el llamarse de Toledo por mucho tiempo le duró hasta que mucho después se pidió en unas cortes se intitulase en segundo lugar de León el rey de Castilla.

Sigue diciendo el jesuita Jerónimo Román de la Higuera (Sánchez Loro, D., pág. 238):

Este año 1189 poco antes el noble rey don Alonso dio un privilegio a la ciudad de Plasencia y a sus vecinos en el que les concede muchos términos. $Y$ por eso creo que tardó algunos años en ponerse en figura de ciudad. Se puede saber por la data del privilegio (1189) demás por las particularidades que en éste hay se puede colergir algo más. No le tienen los placentinos solo sino incorporado a otro del rey don Alonso el Sabio que le contirmó.

\section{El jesuita lo traduce de este modo:}

En los aliende Tiétar séales el lindero cerca del Tajo como divide por allí cl vado de Alarza que está en el Tajo y como van derechamente a Cabeza Mayor de la Pedernalosa. Y de Pedernalosa en derecho a Piedrahíra. Y de Piedrahíta en derecho a Cabezas de Terrazas. Y de Cabezas de Terrazas al derecho hasta entra: en Tiétar. Y adelante el Tiétar a la garganta de Chiella. $Y$ de la garganta de Chiella por aquella carrera recta por do van a lomo de Valvellido. Y por Valvellido como se' iba derecho a Cabeza de don Pedrolo. Y de Cabeza de don Pedrolo ayuso como entra el camino en Tormes. Y por arroyo de Mula atriba a donde entra en Tormes. Y por arroyo de Mula arriba como sale a lomo de Falgoso y de Falgoso ayuso como va a la Calzada de Guinea. Y de la otra parte del Tajo del sobredicho vado de Alarza como sale del camino del vado de Alarza y van por ella al puerto del Ibor sacando el castillo de Albalat con su término que es como caen las aguas hacia el castillo y todas partes desotra parte del Tajo. Y del Puerto del Ibor como derecho al arroyo que se dice Almonte ayuso como cae Geblanco en Almonte. Y Geblanco arriba como se va a Tamuja y en derecho a Cafrán de Montánchez y a la vega de Lucena y a la sierra de San Pedro. Y adelante cuanto pudieren adquirir y ganar los de Plasencia. Y fuera de dichos términos concedo os a Monfragüe por aldea con tal que no tengan castillo... Fue hecha la dicha carta en Plasencia era de 1227 (Año 1189) idus de marzo, dos años después que el serenísimo rey de Castilla y Toledo armó caballero a don Alonso rey de León y el dicho rey de León besó la mano al sobredicho rey de Castilla y Toledo y el sobredicho ilustre rey de Castilla y Toledo armó caballero a Conrado hijo del emperador de somanos y le dio por mujer a su hija doña Berenguela. Y yo el rey don Alonso rey en Castilla y Toledo rubrico y confirmo esta carta con mi propia mano. Hasta aquí llega el privilegio de don Alonso el Bueno. Síguese el de su agüelo don Alonso el Sabio.

La historia manuscrita del jesuita Jerónimo Román de la Higuera (Sánchez Loro, D., pág. 244) afirma lo siguiente:

Es de advertir que el Pontífice Clemente III que fue electo a 24 de dicienbre de 1188 y murió a 25 de marzo de 1191 y fue por todo Papa 27 meses fue el que erigió la iglesia de Plasencia en catedral año 1190 como consta 
de una bula de Honorio III cuya datación doy después desta donde hace mención de la erección que hizo Clemente III. Y dióse a petición del rey don Fernando el Santo en el quinto de su reinado donde señala el mismo distrito a la jglesia de Plasencia. La bula es ésta que se sigue la cual está en el archivo de la iglesia de Plascncia... Vuelta en romance dice: «Después que de todas mancras alabamos la intención real que está ocupada en amplificar o ensanchar los términos de la religión cristiana dícenos por su carta ahora en la tierra que ha ganado del podet de los moros ha edificado una ciudad que se llama Plasencia la cual por autoridad apostolica hacemos catedral. Y le señalamos que tenga diócesis según la disposición real que le debían para siempre pertenecer las villas conforme al presente escrito de Trujillo y Medellín y Almonfrag y Santa Cruz con sus dependencias...» Dada en San Juan de Letrán a 14 de noviembre el quinto año de mi pontificado.

El mismo manuscrito del jesuita Jerónimo Román de la Higuera (Sánchez Loro, D., pág. 248) dice:

$\mathrm{Y}$ tengo por cosa muy averiguada o a lo menos verosímil que Jaraíz y los pucblos que están al norte eran entonces de la vecindad de Jaraíz que como veremos era ya lugar y era ya iglesia de mucha devoción en tiempo de Lucio III papa. El cual concedió muchas indulgencias. $Y$ si entonces se la dieran a la jurisdicción de Plasencia el nombre lo pusiera el Papa.

\section{En una nota Domingo Sánchez Loro dice:}

Es lógico lo que dice el jesuita. Además, si Jaraíz pertenecía a la jurisdicción del obispo de Avila, es bien explicable que en los documentos no se hable para nada de Plasencia.

Vamos a recoger algunos documentos de la Edad Media con el fín de ver los nombres de Extremadura. El 12 de noviembre de 1181 (Barrios, A., pág. 1), el obispo de Avila, Sancho, con consentimiento del cabildo, dona a la orden de San Juan del Hospital de Jerusalén la iglesia de Santa María de la Vega de Olmedo con todos sus derechos de ofrendas y oblaciones y un tercio de sus diezmos. En dicho documento se dice también lo siguiente:

Ego Petrus de Areis Hispaniarum prior cum consensu capituli nostri que in carta scripta sunt firmiter nos observaturos promittimus. Facta carta era MCCXVIIII, 12 noviembre I181, pridie idus novembris. Regnante Aldefonso rege in Castella, Toleto et Extrematura, una cum uxore sua regina Alionore.

El 17 de enero de 1171 (Barrios, A., pág. 10), el arcediano de Olmedo, Juan, dona a la catedral de Avila todo lo que sus padres tuvieron en Olmedo y su término Miguel Serramín y Aldea del Arroyo:

Facta carta donationis in era MCCVIIII, X kalendarum febroarii, regnante rege Aldefonso in Toleto et in Castella et in Strematura, Episcopo Sancto in Avila. 
Hay en la catedral de Avila un documento (Barrios, A., pág. 20) en que Juan Pascual y su mujer venden al obispo abulense una tierra en Caleruca por tres morabetinos:

Dominus Dominicus Abulensis episcopus in propria persona possessiones predicte hereditatis intravit et supradicta terra debet esse XXX operarum et quod defuerit ab codem debet suplerí. Facta era MCCXXI, Regnante rege Aldefonso in Toleto et Castella et Extrematura.

Otro documento (Barrios, A., pág. 19) de 1183 en que Martín y María, hijos de Pelayo, venden al obispo de Avila, Domingo, unas tierras en Caleruca por tres morabetines:

Dominus Dominicus abulensis cpiscopus in propria persona possessionem predicte hereditatis intravit. Facta carta era MCCXXI. Regnante rege Aldefonso in Toleto e Castella et Extrematura.

Hay otro documento de 1183 en que Domingo Longo y Sancho (Barrios, A., pág. 20) venden al obispo abulense, Domingo, una tierra en Caleruca por medio morabetino:

Dominus Dominicus Abulensis cpiscopus in propria persona possessionem predicte hereditatis intravit. Facta carta era MCCXXVI. Regnante rege Aldefonso in Toleto et Castclla et Extrematura.

El 6 de mayo de 1186 (Barrios, A., pág. 25) Urbano III confirma la sentencia dada por los arzobispos de Toledo y Santiago y el obispo de Segovia en el pleito que había existido entre los clérigos y los laicos de la diócesis de Avila. El 2 de enero de 1187 (Barrios, A., pág. 26) Alfonso VIII concede al obispo de Avila y a la catedral la tercera parte de las rentas reales en Plasencia. E1 28 de junio de 1188 (Barrios, A., pág. 27) Clemente III ordena al arcediano, clero y pueblo placentinos mantengan obediencia al obispo de Avila. Dice así:

Clemens episcopus servus servorum Dei dilectis filiis archidiacono, clero et populo placentinis salutem et apostolicam benedicytionem... Alioquin venerabili fratri nostro compostellano archiepiscopo noveritis esse mandatum ut vos ad hoc omni contradictione et appelatione cessante ecclesiastica districtione compellat. Datum Laterani IIII kalendas julii pontificatus nostri anno primo.

En el archivo abulense hay un documento del 1 de julio de 1188 (Barrios, A., pág. 28) de Clemente III confirmando al obispo de Avila el derecho diocesano en Segura y en Plasencia:

Ea propter venerabilis in Christo frater tuis iustis postulationibus grato concurrente assensu diocesanum ius quod in Secura et Placentia que ad culturam noviter sunt redacte et in ecclesiis tue diocesis et territoriis abulense, are- 
valense, ulmetense, securense, placentino positis tam cultis quam incultis habere disnosceris sicut ad te iure canonico pertinet et in cunctis ecclesiis tue diocesis habes salvis privilegiis apostolice sedis et ipsum iuste et pacifice possides auctoritate tibi apostolica confirmamus et presentis scripti patrocinio communimus... Datum Laterani kalendas julii pontificatus nostri anno primo ( 1 julio 1188).

El 7 de junio de 1190 (Barrios, A., pág. 29) Clemente III se dirige a los obispos de Burgos y Oviedo para que intervengan en el pleito que existía entre Plasencia y el obispo de Avila con el fin de que averigüen lo que hay de cierto en las quejas que ha formulado el obispo abulense contra el arcediano de Plasencia. Hay un documento de enero de 1191 (Barrios, A., pág. 30) en que el arzobispo compostelano, Pedro, se dirige al arcediano, clero y pueblo de Plasencia para felicitarles por el aumento territorial de la cristiandad que han logrado y para decirles que de mandato papal recibió el encargo de recordarles que debían aceptar y respetar los derechos diocesanos del obispo abulense.

Hay un acuerdo de 1191 (Barrios, A., pág. 31) del cabildo abulense sobre el reparto de diversos derechos entre éste y el obispo de Avila que contiene varias concesiones de los obispos abulenses del siglo xı, Iñigo, Sancho, Domingo I y Domingo II:

Adicimus etiam quatenus vineas de Porcarizos et domos que fuerunt Petri archidiaconi placentini quas frater eius Johannis de Taiaborch in decisionem litis dedit pro recompensatione illati damni de almoneta quam predictus archidiaconus receperat et canonici in perpetuum habeant... Si vero episcopus a rege in recompensationem Placentic aliquid obtinuerit placuit quod terciam partem canonici cum hiis que de valle abulense percipiunt equis portionibus inter se per capita dividant nec aliquid de his que ad refectorium spectant invitis canonicis nomine sumptus contingere presumat.

En un documento del 7 de abril de 1208 (Barrios, A., pág. 39) el obispo abulense, Pedro, cambia al cabildo el tercio de los diezmos de la iglesia de San Vicente de Avila por lo que tenía en las aldeas de Miguel Serracín Serranos y San Vicente:

Facta carta sub era MCCXLVI, VII idus aprilis (7 abril 1208). Regnante rege Ildefonso et uxore eius Alionor regina in Toleto et in Castella.

Un documento de Inocencio III (Barrios, A., pág. 43) solicita al abad, prior y cantor de Sahagún (León) que intervengan en el pleito que sobre límites diocesanos existía entre el obispo de Avila y el arzobispo de Toledo (13 de mayo de 1212):

«Venerabili fratri nostro toletano archiepiscopo accepimus conquerente quod cum quedam alpes sint que dividunt tholetanam diocesim et dioceses episcopatuum aliorum et predicte alpes inter diocesim tholetanam et alias 
dioceses que sunt pro limitc habeantur, Venerabilis frater noster abulensis episcopus citra illas alpes quasdam ecclesias in eius prejudicium occupavit et alias occupare contra iusticia non veretur.

El día 11 de agosto de 1212, el abad prior y cantor de Sahagún notifican al obispo de Avila que vaya a Medina de Rioseco para oír la sentencia sobre el pleito que tenía con el arzobispo de Toledo sobre límites diocesanos (Barrios, A., pág. 44). El 4 de septiembre de 215 (Barrios, A., pág. 45), el abad prior y cantor de Sahagún, a pesar de los alegatos del procurador abulense, se pronuncian a favor del arzobispo de Toledo en el pleito que sobre la posesión de algunas iglesias mantenía éste desde hacía algún tiempo con el obispo y cabildo de Avila. Dice así el documento:

Libellus autem conventionalis talis est. Ego Gillemus procurator domini R. toletani archiepiscopi in causa que inter ipsum vertitur ex una parte et dominum Petrum abulensem episcopum est adversa coram abbate, priore et cantore Sancti Facundi iudicibus a domino papa delegatis peto a predicto domino Petro abulensi episcopo ecclesiam de Verraco et has alias ecclesias scilicet de Ponte de Alvareche, de Sancta Maria de Tremulo, de Sancta Maria de Tortoles et monasterium Sancte Marie de Fundo et omnes alias ecclesias que sunt ab his terminis versus Alfamyn, Cadafalsum, Scalonam et Talaveran videlicet ab albergaria Muni Mathei recta distensione usque ad portam de Pico sicut ad ipsa albergaria omnes aque recurrunt cadentes in Alvareche et in Tietar usque ad portam de Pico et a predicta albergaria Muni Mathei recta distensione usque ad locum illum ubi dividitur abulensis diocesis cum Secobiensis diocesis secundun quod ad ipsa albergaria omnes aque decurrunt cadentes in Gaznata et in Alvareche usque ad predictum locum ubi dividitur abulensis diocesis cum secobiensi diocesi... Haec acta sunt apud Sanctum sub era MCCLIII pridie nonas a septembris in claustro infirmorum.

Existe en el archivo de la catedral abulense una bula de Honorio III solicitando al obispo de León y arcediano de Osma que intervenga en el pleito que sobre derechos de algunas iglesias mantenían el arzobispo de Toledo y el obispo de Avila de 20 de diciembre de 1216 (Barrios, A., pág. 47). También hay otra bula de Honorio III de 2 de abril de 1217 en la que el papa ordena al obispo, al sacristán y a un canónigo de Burgos den solución en el pleito mantenido entre el arzobispo de Toledo y el obispo de Avila (Barrios, A., pág. 47). Existe una bula de 9 de junio de 1217 (Barrios, A., pág. 48) en que Honorio III se dirige al obispo, deán y chantre de Zamora para que intervengan en el pleito que sobre la villa de Béjar y su término mantenían los obispos de Plasencia y Avila:

Honorius episcopus servus servorum Dei venerabili fratri episcopo et dilectis filiis decano et cantori Zamorensis salutem et apostolicam benedictionem. Venerabilis frater noster abulensis episcopus nobis conquerendo mostravit quod venerabilis frater noster episcopus placentinus ecclesias de villa Bejal et de suo termino et quasdam alias ad ipsum de iure spectantes contra iustitia detinet occupatas... Data Anagnie, V idus junii pontificatus nostri anno primo. 
Honorio III, el 14 de noviembre de 1221 , confirma la erección del obispado de Plasencia a pedimento de Fernando III (Sánchez Loro, D., pág. 52). El 20 de noviembre de 1223, Honorio III vuelve a mandar al obispo, deán y chantre de Zamora que den una sentencia justa para concluir el pleito que sobre las iglesias de Béjar y su término inantenían los obispos de Plasencia y Avila (Barrios, A., pág. 52):

Venerabilis frater noster episcopus et dilecti filii capitulum abulensis nobis insinuare curarunt quod cum idem episcopus super ecclesiis de Bejar ac eius termino et quibusdam aliis ad ipsos spectantibus nostras ad vos litteras de capitulo ipso mentione nos habita impetrasset contra episcopum placentinum, placentino capitulo asserente quod ecclesie ipse pro indiviso possidebantur ab eis et prefato episcopo placentino reclamante re procederatis in causa cum littera ipse de capitulo eodem non mentionem vos in ipso non duxistis negotio procedente propter quod causa eadem dudum remansit in abulensi ecclesie periudicem indecisa... Data Laterano XII kalendas decembris pontificatus nostri anno octavo.

En el archivo abulense hay un escrito de Alfonso X del 12 de agosto de 1268 ordenando a los hombres que labran en el Campo de Arañuelo que paguen debidamente a la iglesia de Avila los diezmos (Barrios, A., pág. 84):

Don Alffonso por la gracia de Dios rey de Castiella de Toledo de Leon de Gallizia de Sevilla de Jahen de Murcia de Cordova e del Algarbe a los pueblos de Valdeeglesias de Torralva de Berceal e de la Fiente del Sapo e a todas las otras pueblas que son de la Fuente del Sapo fasta Valffonsadero e a todos los otros omes que labran en el Canpo de Arannuelo que son en el obispado de Avila salut e gracia. Sepades que don Frey Domingo Suarez obispo de Avila se me querello e dize quel non quieredes dar sus diezmos que deve aver en vuestros lugares et maravillo io mucho por que lo fazedes. Onde vos mando quel dedes todos sus dliezmos e sus derechos bien e complidament assi conmo los deve aver obispo de Avila. Et non fagades ende al, si non, mando a los alcalles c a la justicia de Avila que vos los fagan dar. Dada en Sevilla el rey la mando domingo XII dias de agosto era de mille et CCC e seys annos.

En el archivo de Avila hay un documento real de Alfonso X, de 12 de octubre de 1281, ordenando a los vecinos de los lugares del Campo de Arañuelo que den décimas y primicias a la iglesia de Avila, reservando para él el derecho de patronazgo de la iglesia de Oropesa (Barrios, A., pág. 94). Estos documentos dan a conocer ciertos datos sobre límites entre las diócesis de Avila y de Plasencia. Hemos traído el texto latino con el fin de dar el texto indiscutido sobre las discusiones de fronteras y linderos antiguos.

El rey Alfonso VII, el 15 de marzo de 1155 , señala los límites del alfoz de Avila: «Tajo abajo hacia el Tiétar — Tiétar arriba donde el arro- 
yo de Pasarón Mayor cae en el liiétar - Pasarón arriba hasta donde nace» (Rivera, J., pág. 9; Muñoz García, J., Antiguas ordenanzas de Béjar, pág. 155). En 1189, Alfonso VIII realiza el amojonamiento dando como límites del alfoz de Plasencia «en el sector oriental el río Tiétar y desde el río Tiétar la garganta de Chilla arriba hasta su nacimiento siguiendo posteriormente por la cumbre de la sierra» (Rivera, J.; Alonso Fernández, Historia y anales de la ciudad y obispado de Plasencia, Cáceres, 1952, pág. 26). El año 1205, Alfonso VIII deslinda los términos de Avila de la siguiente manera: «... lugar donde nace el Jaranda - Jaranda abajo donde cae en el Tiétar - hacia abajo donde cae en el Tajo...» (Rivera, J., pág. 9; Muñoz García, J., Antiguas ordenanzas de Béjar, pág. 163).

Fernando III media en las discordias entre Plasencia y Avila por los límites del término jurisdiccional, confirmando el amojonamiento de Alfonso VIII. A finales de su reinado, en 1248, los concejos de Plasencia y Talavera firman una alianza (Rivera, J., pág. 11; Vergara Martín, G., Estudio bistórico de Avila, Madrid, 1896, págs. 189-190):

Nos el concejo de Plazencia et de Talavera con saber de fazer mejor vida de consuma, et por nos defender a muchas fuerzas et a muchas tuertos e a muchas soberbias que sofrimos, et avemos sufrido grant sazon ha de muchas guisas del concejo de Avila, paramos nuestra amizdad de consuma firme y estable contra el conccjo de Avila e contra quantos en su ayuda vinieren.

La Crónica de la población de Avila, escrita con posterioridad a 1255 , afirma que «en este tiempo de Avila contra los moros non avia pueblo de cristianos sino es una torre que es en las Ferrerias» (Rivera, J., pág. 15; Crónica de la población de Avila, pág. 31). Tras la derrota de Alarcos (1195), «el moro enemigo corrió arrogante las tierras de Toledo y Extremadura talando, entre otras muchas, las comarcas de Talavera, Plasencia y Trujillo y hasta intentó traspasar las sierras para entrar en Castilla» (Rivera, J., pág. 15; Martín, J., Hisloria de Avila, Avila, 1872, pág. 333).

Parece que con Alfonso VII se repuebla la parte sur de Gredos, pues el rey, en 1150, dona San Martín de Valdeiglesias al monasterio de Santa María. Probablemente antes de esa fecha se estableció algún núcleo al sur de la sierra de Gredos, concretamente el monasterio de San Vicente de la Sierra, tanto o más al amparo de esta sierra de San Vicente y de la cercana Talavera como al de la lejana Avila, «pero la repoblación allí era lenta en gran parte por la calidad de la tierra» (Rivera, J., pág. 15).

En un juicio celebrado en 1431 se dice (Rivera, J., pág. 19; Paredes Guillén, V., Los Zuñiga, señores de Plasencia, Cáceres, 1903, pág. 75):

Preguntados si los del término de Candeleda... lugar del Xonde de Ledesma en el término de Avila sy saben o creen o vieron o oyeron decir que tu- 
vicsen o obiesen tomado algunos términos de la dicha cibdad dixeron que oycron decir en otros tiempos antiguos que la garganta que dicen de Chilla aquenck que era del término de Plasencia e que agora y lo defienden descle la garganta de Chilla fasta la garganta de Lardos que ha vuelta de media legua de tierra e que lo han tomado e que no guarda sinon desde la dicha garganta de Lardos acjuende; pero que en sus tiempos dellos ny nunca se ha podido decir que fuesc tomado término alguno allí, e por que oyeron decir que la deslindación de aquella tierra que estaba en el arca del Concejo de dicha cibdad.

El 15 de noviembre de 1373, Enrique II concede a Candeleda una dehesa. J. Rivera fotografía el documento en la página 20 y la confirmación de los Reyes Católicos en la portada. Copiamos el texto de Enriụue II, citado por J. Rivera, página 21:

Don Linrique por la gracia de Dios rey de Castilla de Toledo de León de Galicia de Sevilla de Cócloba de Murcia de Jaén del Algarbe de Algecira e Señor de Molina. Al Concejo e a los Alcaldes e alguacil de la ciudad de Avila... Salud e gracia, sepades que el Concejo e homes buenos de la Candaleda (en la fotografía de la portada se lee perfectamente «Candalecla»; «cándalo» es pinar, y «candaleda», conjunto de pinares) aldea de Avila se nos embiaron querellar e dicen que ellos que han una dehesa suya en término del dicho lugar la cual diz que empieza desde donde nace el río Ruecas hasta do da la garganta de Santa María a la garganta ayuso hasta do da en Tiétal e 'Tiétar ayuso e hasta do nace (debería decir «hasta do da») Alardos e Alardos arriba hasta do nace y la cumbre adelante hasta do daba en Ruecas, de la cual dehesa dixo que tenía cartas en como se la dio e amojonó Pero Beltrán de Izana alcalde y entregador de los pastores de la Cañada Segoviana que era a la sazón por el rey clon Sancho nuestro bisabuelo e confirmada de él é del rey don Fernando nuestro abuelo e del rey don Alfonso nuestro padre que Dios perdone scgún que se contenía en un traslado de las dichas confirmaciones signado de escribano público que el dicho Concejo nos enviaron mostrar: en esta suzón en que parece que es así, el cual llevaron para guarda de su delecho e otrosí nos enviaron mostrar una carta del tirano que se liamaba rey (Pedro I) sellado con su sello de plono colgado en que se contenía que les mandaba guardar la dicha dehesa e que ponía pena cierta contra aquellos que en la dicha dehesa contra su voluntad. E agora diz que hay algunos que les entran a pacer con sus ganados y cortar madera contra su voluntad en la dicha dehesa no lo pudienclo ni debiendo hacer de derecho... carta ley... dada en Toro quince días de noviembre era de mil e cuatrocientos y once años (1373).

J. Rivera pone en la página 33 la foto y en la 31 transcribe la confirmación del privilegio de villa de Candeleda por los Reyes Católicos ototgado por Enrique II el 14 de octubre de 1393:

Don enrrique por la gracia de lios Rey de castilla de leon de toledo de galicia cle sevilla de cordoba de murcia de jahen del algarbe de algecira u señor de vizcaya e de molina... por hacer bien y merced a vos el concejo e homes buenos de la candeleda se pueble y hasga mejor hago villa e lugar sobresy al dicho lugar dela candeleda... es mi merced que vos el dicho lugar dela candeleda que yo hago villa ayades por terunino y por cosa vuestra para 
vosotros todo el termino que vos aviades y de que usavades vos pertenescia en qualquyer manera seyendo aldea y con sus dehesas y montes y prados e aguas corrientes e estantes e con todas las casas y poblado e alijares e vecinos e moradores... E otrosy dovos (os doy) mas por termino y por cosa vuestra a las casillas con todos sus vecinos e pertenencias. E por vos fazer mas bien c mas merced otorgo vos que podades hazer mercado un dia en la semana qual vos para ello escogierdes e quisierdes... vos el dicho lugar dela candeleda esentamente seades villa e lugar sobresy e ansy essento con los dichos terminos... por en este caso la dicha ley de brivyesca... dada en Madrid catorze dias de octubre año del nascimiento cle nuestro señor jesucristo de mill tresientos y noventa y tres años. yo ruy lopez la fize escrevir por mandato de nuestro señor el rey.

J. Rivera, en la página 35, cita un texto de Vicente Paredes (Los Zúñiga..., pág. 80) que dice:

... otrosy que saben que la garganta que dicen Gualdeminos que está cerca de Valverde entre las Casillas y Solóbriga...

En otro lugar (pág. 78) Vicente Paredes dice:

... que tienen señaladas a las alcarrias del dicho lugar de Madrigalejo (hoy, Madrigal de la Vera) e las Casillas e Salobrar e Viandar...

Tomás López, en su mapa de 1760, cita a Salobrar entre Minchones y Galabranos. En Jaraíz de la Vera está la ermita donde se venera la imagen de Nuestra Señora del Salobrar. En el río Tiétar existen ruinas de la antigua ermita del Salobrar, cerca del actual puente de Casatejada y cerca de Mesillas.

En Avila (Rivera, J., pág. 37; Martín, J., Historia de Avila, pág. 414), el sábado 5 de junio de 1395, el alcalde juntamente:

... de los doze cavalleros, escuderos y hombres buenos en presencia de Juan Sáenz de Burgos escribano del rey otorgaron lo dicho la confirmación de los pueblos y tierra que el rey dio a Rui López Dávalos su camarero como fueron el Colmenar (Mombeltrán), Arenas, Candeleda...

La crónica de Juan II (Rivera, J., pág. 38) narra la cesión de Candeleda a Pedro de Zúñiga:

... e a Pedro de Zúñiga Justicia Mayor del Rey dio a Candeleda con ciertas herrerías cue allí tenía el Condestable don Ruy López Dávalos Valdeverdeja pertenecía à condado de Miranda como Candeleda.

En el siglo xvi, Fernando Colón (Rivera, J., pág. 38; Colón, F., Descripción y cosmografía de España, 1517, facsímil) habla de esta comarca de la sierra de Gredos: «Candeleda es lugar de trescientos vecinos, está en llano al pie de la sierra que se llama sierra de gredo ( sic) que es la más 
alta syerra que ay en toda españa e es el lugar del conde de miranda e tiene buena fortaleza» (Fig. 1).

En el censo verificado por el canónigo placentino Tomás González en 1594, Candeleda tiene 393 vecinos (Rivera, J., pág. 41). En el manuscrito de la renta del tabaco de 1752, Candeleda tenía 1.890 moradores.

El estado de Miranda o estado de Candeleda y Valdeverdeja no forman un estado homogéneo y continuo, ya que «salvo Valdeverdeja, que pertenece actualmente a la provincia de Toledo, y Candeleda, que queda hoy día en la de Avila, las otras villas del señorío de los Condes de Miranda (cerca de Béjar), que figuran como de aquel partido en 1753 - Berrocalejo, Bohonal, El Gordo, Talavera la Vieja, Puebla de Enaciados-, pertenecen actualmente a la provincia de Cáceres» (Rivera, J., pág. 43; Moxo, S., Antiguos señorios de Toledo, pág. 94).

Por esa época Candeleda figura dentro de los límites de Avila, en el catastro de Ensenada, pero no en el manuscrito de la renta del tabaco, que nos sirve de guía principal en el ámbito geográfico y aun administrativo (Rivera, J., pág. 43; Martín, J., Historia de Avila, pág. 112).

La situación de los pueblos que integraban el estado de los Condes de Miranda rebasa en importancia a su identidad intrínseca y dimana de su emplazamiento en pleno itinerario ganadero, pues de Segovia partía uno de los ramales de la gran cañada que, cruzando el sistema central por el puerto de Candeleda, alcanzaba el paso del Tajo por Berrocalejo, con dirección a los pastos del sur, al mismo tiempo que de la propia Candeleda partiría un itinerario análogo al que enlaza hoy esta localidad con Plasencia por la Vera (Rivera, J., pág. 49; Moxo, S., Antiguos señorios de Toledo, pág. 95).

La cañala segoviana se internaría en tierras de Candeleda, de norte a sur, a través del puerto de Candeleda, para llegar a través del puente del puerto hasta el descansadero de la Cañada; desde aquí seguiría su itinerario hasta el Vado Concejo, donde se internaría en las dehesas camino de Berrocalejo.

En el archivo municipal de Piedrahíta, tomo I, cuarto de becerro, existe un escrito que dice: «Documento con licencia que dio el Obispo de Plasencia para hacer el Puer to de Candeleda y repartimiento de dineros para lo hacer» (Rivera, J., pág. 49). Tal documento es de fecha 1510.

La razón que se aduce es «que se ahorra una jornada para ir o venír a Puente del Arzobispo, Guadalupe y Andalucía, con ventaja para el comercio de ganados, frutas, aceite y otras cosas que por el puerto del pico tardan un día más» (Rivera, J., pág. 49; cit. por Barrios, A., El alto valle del Tormes, pág. 10).

En 1594, en los censos de Tomás González, encontramos referencias sobre el número de ganados que utilizan el puerto de Candeleda, o como 
los llama el censo, «puerto de travesío y contadero de la corona de Castilla». En el año 1477 utilizan el puerto 42.405 cabezas de todo ganado. En 1563 el número de cabezas de ganado lanar y cabrío suma 33.888, siendo 1.312 las vacas que pasan por el puerto de Candeleda, lo cual demuestra la escasa transhumancia que utiliza este puerto, principalmente por el «desfiladero que no tiene menos de 2.000 metros de altura y no resulta fácilmente accesible por una transversal desde el norte) (Rivera, J., pág. 49; Aitken, R., Rutas de la transbumancia, Madrid, 1947, pág. 196). La cantidad de ganado que utiliza una cañada repercute en los ingresos que por los distintos impuestos se carga al ganado transhumante. El más importante quizá sea el montazgo, que es un tributo permanente que tenían que pagar todos los transhumantes bien sea como peaje o para poder hacer uso de los pastos públicos de la ciudad. El portazgo, otro de los impuestos característicos de la transhumancia, es un tributo derivado del paso de ciertas propiedades, como eran las cañadas y puertos.

Ambos impuestos se fundicron posteriormente en uno sólo, que se denominó servicio y montazgo. «Era de una gran importancia tomar nota de este intento de sistematizar y concretar los portazgos locales en centros debidamente autorizados para la recaudación porque éste era el modelo empleado como base para el sistema de puertos tealcs» (Rivcra, J., página 5l; Klein, J., La mesia, Madrid, Alianza Universidad, 1981, pág. 179). En este estudio de fronteras vamos a mencionar la historia de Mérida y su arzobispado. Gredos era término de Lusitania. El 27 de febrero de 1120, Calixto II nombra a Gelmírez su legado en las provincias emeritense y bracarense y concede a Santiago de Compostela la dignidad metropolitana: «Donec disponente Deo Emeritana civitas christiano potentatui restituta cardinalem meruerit antistitem obtinere.»El 21 de junio de 1121, Calixto II faculta a Gelmírez para que procure la obediencia de los obispos de Coimbra, Mondonedo y Lugo, evitando presionar al bracarense.

E. 3 de noviembre de 1121 , Calixto II instituye a Bernardo de Toledo legado pontificio en España, excepto en las provincias emeritense y bracarense.

El 29 de noviembre, Calixto II ordena al arzobispo bracarense y a los obispos de Coimbra, Oporto, Tuy, Caldas del Rey, Valeria, Lugo, Astorga, Avila, Salamanca, a los abades y demás clero de las provincias bracarensc y emeritense que obedezcan a Gelmírez, según su condición de arzobispo de la provincia emeritense y legado pontificio para las provincias bracarense y emeritense.

El 24 de junio de 1124 hay una bula de traslado definitivo de la dignidad arzobispal de Mérida a Compostela: 
Fraternitatis ergo tuis petitionibus annuentes, Compostellane Beati Iacobi Ecclesiae, cuius in ea venerandissimum corpus creditur esse possitum, ob ipsius i Deo dilecti Apostoli reverentiam Archiepiscopalis Cathedre dignitatem quam ei ad tempus concesseramus donec Emeritana civitas christianorum dominio et cultui redderetur, presentis pagine auctoritate in perpetuum confirmamus.

En esta misma bula de Calixto II se ordena a Munio, de Salamanca, que obedezca al arzobispo compostelano como a metropolitano propio. El 24 de marzo de 1129, Alfonso VII promete donar a Compostela la ciudad de Mérida una vez reconquistada. lil 21 de octubre de 1170, Fernando II confirma la promesa de su padre, Alfonso VII. El 31 de mayo de 1229, Alfonso IX confirma la promesa de su padre y abuelo. El 20 de julio de 1230, Alfonso IX dona la ciudad de Mérida (Fig. 5), reconquistada, a la iglesia de Compostela.

Gregorio IX firma dos bulas para el arzobispo compostelano el 29 de octubre de 1230. La primera concede la facultad para que se constituyan cabildos y se consagren obispos en las ciudades de Mérida y Badajoz. La segunda dispensa a los posibles candidatos de las irregularidades $e x d e$ fectu hatalium en virtud de las especiales circunstancias de tiempo y lugar, así como de cualuguer inhabilidad para la colación canónica del oficio.

El 26 de junio de 1234, Gregorio IX vuelve a insistir, en bula dirigida conjuntamente a los arzobispos de Toledo y de Santiago, para que no se demoren en sus respectivas provincias la ordenación de obispos en aquellas ciudades que antes lo tuvieron. Como consecuencia, el compostelano don Bernardo elige para obispo de Mérida al maestro Alfonso; pero después de haberlo investido de su anillo se nicga a ordenarlo, por lo cue el electo acude a la curia, ordenándose la instrucción de un proceso. El 3 de octubre de 1234 hay una bula para que el obispo de Lugo inicie el proceso. El 19 de mayo de 1235, Gregorio IX escribe a los obispos de Orense y Lugo encomendándoles ciue acepten la renuncia de don Bernardo en virtud de que padece larga e incurable enfermdad.

E.l 19 de mayo de 1235 otra bula faculta a los citados obispos para que puedan absolver ad cautelam al arzobispo compostelano de la censura de excomunión. El 17 de julio de 1236 hay una bula pontificia al obispo de Astorga para que ejecute la resolución dictada. El cardenal Otón casó la provisión no por inhabilidad de la persona elegida, sino por vicio de procedimiento. El papa se hizo la reserva para proceder directamente a la provisión: «Nobis provisione ipsius Emeritensis ecclesie reservata», que hasta hoy no se ha llevado a efecto. La orden militar de Santiago y el arzobispo compostelano se otorgan mutuamente, el 14 de febrero de 1171 , carta de hermandad. El arzobispo entra en la orden militar y el maestre como canónigo compostelano. 
Se cede a la orden militar la cuarta parte de la ciudad de Mérida con una de las mejores capillas y la mitad de su término. La orden militar de Santiago comienza adquiriendo unos derechos de copartícipe en la ciudad de Mérida y termina siendo dueña absoluta el 22 de abril de 1254, ya que el arzobispo compostelano otorga la posesión total de la ciudad de Mérida a la orden militar a cambio de algunas posesiones. El 4 de mayo de 1254 una bula de Alejandro IV aprueba la cesión anterior.

El 18 de mayo de 1571 , a petición de Felipe II en calidad de administrador perpetuo de la orden de Santiago, San Pío V promueve al párroco de Santa María de Mérida a obispo titular de Túnez, con facultad de ejercer de pontifical en todo el territorio de la orden, pero siguiendo como párroco de la citada iglesia y sin merma alguna de las facultades de los priores de San Marcos de León y Uclés. Con él se inicia la serie de estos obispos titulares in partibus infidelium residentes en Mérida, diez en total, hasta 1797. Actualmente han nombrado dos nuncios apostólicos arzobispos titulares de Mérida.

El concordato entre la Santa Sede y España de 16 de marzo de 1851 señaló a Plasencia y Coria en la provincia eclesiástica de Toledo, y a Badajoz en la provincia eclesiástica de Sevilla. En el concordato de 1953 la situación permanece inalterable en la región extremeña. Se ban creado en estos últimos años los arzobispados de Madrid, de Barcelona, de Pamplona, de Oviedo. Sin embargo, el arzobispado de Mérida no ha sido restablecido. Leocadio Curiel, arcipreste de Plasencia, fallecido en accidente de tráfico en 1984 en la carretera de Mérida a Cáceres, no lejos de la ermita visigótica de Santa Lucía, en las sierras de Montánchez, tierras antiguas de la diócesis placentina, ha estado trabajando incansablemente en colaboración con numerosas personalidades extremeñas para el restablecimiento del arzobispado emeritense. Han publicado un libro de la Iglesia extremeña, impreso en la imprenta Sánchez Rodrigo, en 1977. Mi recordado amigo Aquilino Camacho Macías ha defendido en Roma, en 1965, su tesis doctoral La antigua sede metropolitana de Mérida.

Damos una lista de los primeros obispos de Mérida. Hacemos constar de este modo que hubo población desde la época romana hasta la época visigótica y medieval: Marcial (255), Félix (255), Liberio (295-314), Florencio (347-380), Idacio (380-400), Patruino (400), Gregorio (410-420), Antonino (445-449), Zenón (483), Paulo (530-560), Fidel (560-571), Masona (571-605), Inocencio (605), Renovato (633), Esteban (633-635), Oroncio (635-665), Proficio (665-671), Festo (671-681), Esteban II (681-685), Máximo (688), Ariulfo (839-862). El 18 de junio de 1968 tuve yo una comunicación sobre el arzobispado de Mérida en la Edad Media en el Congreso Luso-Español de Oporto (Portugal), en el XI Centenario de Vimara Peres. Se han publicado las actas. 


\section{BIBLIOGRAFIA}

Alvarez, José María, y Ordnx, Andrés: Muestra de arte e bistoria, Cáceres, 1984. Alvarez del Villar, Julián, y Gonzílez, Julio: Extremadura, Ed. Noguer-Fundación March, 1.` ed., 1979; 2." ed., 1984.

Barrios, Angel: Documentación medicval de la catedral de Avila, Ediciones de la Universidad de Salamanca, 1981.

RiverA, Jesús: Algunas notas y comentarios para una bistoria de Candeleda, Imprenta A. Jiméné, Candeleda (Avila), abril 1983.

Sánchez Alegría, Eleuterio: Ruta de la Vera de Plasencia (Guía histórica de la comarca turística de la sierra de Gredos, entre Extremadura y Castilla), Barcelona, 1984.

SÁnchez Loro, Domingo: Historias placentinas inéditas, Ediciones Institución el Brocense, Cáceres, 1982.

Sobrino Chomón, Tomás: Episcopologio abulense (siglos XVI-XVIII), Institución Gran Duque de Alba, Avila, 1984.

Soria Sínchez, Valentín: Actas del Congreso Luso-Españal de Oporto (Portugal), 1968. 